\title{
Effect of sterilization methods on the absorption capacity of absorbent paper points
}

\section{Efeito dos métodos de esterilização na capacidade de absorção de pontas de papel absorvente}

\author{
Carlos Menezes AGUIAR \\ Associate Professor - Department of Prosthetics and Oral and Facial Surgery - Faculty of \\ Dentistry - Federal University of Pernambuco - Recife - PE - Brazil.
}

\section{Thaísa TORRES \\ Private Practice}

\section{Daniela de Andrade MENDES \\ Bruna FARIAS}

Student of MSc Course in Integrated Clinical Dentistry - Department of Prosthetics and Oral and Facial Surgery - Federal University of Pernambuco - Recife - PE - Brazil.

\author{
Andréa Cruz CÂMARA \\ Department of Prosthetics and Oral and Facial Surgery - Faculty of Dentistry - Federal \\ University of Pernambuco - Recife - PE - Brazil.
}

\begin{abstract}
ABSTR ACT
The purpose of the present study was to analyze the influence of sterilization methods on the absorption capacity of different brands of standardized absorbent paper points, testing the hypothesis that there is a positive correlation between the percentage of increased absorption capacity and sterilization method. Standardized endodontic absorbent paper points (size rank from \#15 to \#40) from three different brands of three manufacturers were used for this study (Dentsply, Endopoints, Tanari). Twenty absorbent paper points of each size were used. The initial weight (iw) of each absorbent paper point was recorded using a digital scale. After sterilization, the dry weight (dw) of each absorbent paper point was determined. Each paper point was then introduced into a 2\% methylene blue solution during 20 seconds until complete saturation. The paper points were removed from the solution and the wet weight (ww) was determined, with absorption capacity calculated from a difference between ww-dw. Data was statistically analyzed using Tukey's test and the Student's $\mathrm{t}$-test $(\mathrm{p}<0.05)$. Tanari paper points exhibited the best absorption capacity among the brands analyzed, but the difference was non-significant. Sterilization process did not influence the absorption capacity of absorbent paper points.
\end{abstract}

\section{KEYWORDS}

Endodontics; pulp cavity; sterilization.

\section{INTRODUCT ION}

One of the most important treatment procedures for optimizing a long-term clinical success of root canal treatment is the adaptation of material along the walls of root canal system and apical foramen [1]. Root canal sealing has played an important role in dental therapy and biomechanical preparation by itself is not capable of disinfecting root canals [2-4].
The purpose of root canal filling is to fill the pulp space with three-dimensional root canal filling, which cannot be achieved if canal is not dried beforehand [5]. Drying root canal is therefore an important step for successful hermetic sealing, given that adhesion and physicochemical properties of filling materials are altered by moisture. Standardized absorbent paper points are extensively used in endodontic therapy following irrigation in order to dry the wall of the root 
canal [6]. Paper points are also used to apply intracanal medication, remove microbial cultures from the canal and as an indicator of the quality and color of the canal exudate [7]. However, little attention has been paid to the assessment of biological, physical, and mechanical properties of this dental accessory $[5,8,9]$.

Paper points must exhibit an adequate capacity for absorbing liquids in order to dry root canals. Less time and fewer points are needed to dry root canals when paper point exhibits greater absorption capacity [8]. Few studies report on absorption capacity of paper points [1,5,6,9,10]. Pereira et al. [7] analyzed two different methods for assessing absorption capacity of absorbent paper points. However, little attention has been paid to the assessment of the influence of sterilization methods on the absorption capacity of absorbent paper points.

The purpose of the present study was to analyze the influence of sterilization methods on absorption capacity of the three brands of standardized endodontic paper points, testing the hypothesis that there is a positive correlation between the percentage of increased absorption capacity and sterilization method.

\section{Materials and Methods}

Standardized endodontic absorbent paper points (size rank from \#15 to \#40) from three different brands of three manufacturers were used for this study: Dentsply (Dentsply Indústria e Comércio Ltda., Petrópolis, Brazil), Endopoints (Endopoints Indústria e Comércio Ltda., Paraíba do Sul, Brazil) e Tanari (Tanariman Industrial Ltda., Manaus, Brazil). Twenty absorbent paper points of each size were used. A total of 360 points were tested.

Each dry absorbent paper point was weighed on an electronic laboratory balance to a precision of \pm 0.0001 (Gehaka, São Paulo, Brazil), thereby determining the initial weight (iw). The paper points were then randomly divided into three groups: Group 1 - no sterilization process; Group 2 - wet heat sterilization $\left(121^{\circ} \mathrm{C} / 15 \mathrm{psi} / 30 \mathrm{~min}\right)$-(Cristófoli, Campo Mourão, Brazil); Group 3 - dry heat sterilization $\left(170^{\circ} \mathrm{C} / 60 \mathrm{~min}\right)$-(Odontobras, São Paulo, Brazil). In Groups 2 and 3, the absorbent paper points were submitted to a single sterilization cycle. Following sterilization, paper points were weighed again to determine the dry weight (dw).

Five $\mathrm{mm}$ of each absorbent paper point was introduced into a $2 \%$ methylene blue solution during
20 seconds until complete saturation [10]. Points were removed and immediately weighed to obtain the wet weight $(\mathrm{ww})$. The increase in mass $(\mu \mathrm{g})$ was calculated from the difference between wet weight and dry weight.

Data were submitted to statistical analysis with the use of a linear model to reveal significant interactions between caliber, brand and type of sterilization. Analysis of variance (ANOVA) was used to compare three or more measurements. When appropriate, Tukey's test was used for multiple comparisons. The Student's t-test was used to compare mean values between two groups. The level of significance for all statistical tests was set at $0.05(\mathrm{p}<0.05)$.

\section{Results}

Table 1 displays a comparison of mean wet weight values between brands, controlling caliber and type of sterilization. In each of the 12 possible combinations of caliber and type, ANOVA revealed differences in mean wet weight values of the paper points. Tukey's test for multiple comparisons revealed that mean weight wet value was generally significantly lower of Dentsply brand (Dentsply Indústria e Comércio Ltda., Petrópolis, Brazil), followed by that of Endopoints brand (Endopoints Indústria e Comércio Ltda., Paraíba do Sul, Brazil). Tanari brand (Tanariman Industrial Ltda., Manaus, Brazil) had a tendency to achieve the highest mean wet weight values.

Table 2 displays comparisons in mean weight gain (absorption capacity) of the points in the first series sterilized in dry heat, according to caliber and brand. Dentsply brand (Dentsply Indústria e Comércio Ltda., Petrópolis, Brazil) never achieved a significantly higher absorption capacity than the other brands in any of the comparisons, whereas the Tanari brand (Tanariman Industrial Ltda., Manaus, Brazil) never achieved a significantly lower absorption capacity than the other brands in any of the comparisons.

Table 3 shows that comparisons of absorption power of the points in the first series sterilized in an autoclave, according to caliber and brand. Dentsply brand (Dentsply Indústria e Comércio Ltda., Petrópolis, Brazil) never achieved a significantly higher absorption capacity than the other brands in any of the comparisons. In nearly all comparisons (except those for caliber 15), Tanari brand (Tanariman Industrial Ltda., Manaus, Brazil) achieved either a significantly higher absorption capacity or equal absorption capacity in comparison to the other brands.

Table 4 compares absorption capacity of Cell 
Pack point (Dentsply Indústria e Comércio Ltda., Petrópolis, Brazil) from Dentsply (Dentsply Indústria e Comércio Ltda., Petrópolis, Brazil) to points from the same brand sterilized in either an autoclave or dry heat. There was no evidence of a significantly greater absorption capacity of the Cell Pack points (Dentsply
Indústria e Comércio Ltda., Petrópolis, Brazil) in comparison to that of Dentsply (Dentsply Indústria e Comércio Ltda., Petrópolis, Brazil) points sterilized in dry heat or autoclave. Absorption capacity of the absorbent paper points was not influenced by sterilization process.

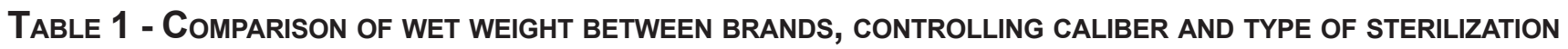

\begin{tabular}{c|c|c|c|c|c|c|c}
\hline & & \multicolumn{3}{|c|}{ Mean Wet Weight $(\mu \mathrm{g})$} & \multicolumn{3}{c}{$p$-values of Tukey's multiple comparison test } \\
\hline Caliber & Sterilization & Dentsply (1) & Endopoints $(2)$ & Tanari (3) & $(1) \times(2)$ & $(1) \times(3)$ & $(2) \times(3)$ \\
\hline 15 & Dry heat & 4.0 & 5.5 & 5.5 & 0.000 & 0.000 & 0.993 \\
\hline \multirow{2}{*}{20} & Autoclave & 4.1 & 5.4 & 5.1 & 0.000 & 0.000 & 0.043 \\
\hline \multirow{2}{*}{25} & Dry heat & 4.9 & 6.0 & 6.8 & 0.000 & 0.000 & 0.005 \\
\hline \multirow{2}{*}{30} & Autoclave & 5.1 & 6.1 & 6.6 & 0.000 & 0.000 & 0.009 \\
\hline \multirow{2}{*}{35} & Dry heat & 6.1 & 6.9 & 9.5 & 0.069 & 0.000 & 0.000 \\
\hline & Autoclave & 6.3 & 7.0 & 9.3 & 0.006 & 0.000 & 0.000 \\
\hline 40 & Dry heat & 7.8 & 8.6 & 10.4 & 0.129 & 0.000 & 0.001 \\
\hline & Autoclave & 7.7 & 8.9 & 10.1 & 0.000 & 0.000 & 0.000 \\
\hline & Dry heat & 8.5 & 11.1 & 13.1 & 0.000 & 0.000 & 0.000 \\
\hline
\end{tabular}

* Values are in scientific notation

Table 2 - Mean weight gain in mg of Paper points Sterilized in a DRY heat, ACcording to caliber AND BRAND

\begin{tabular}{c|c|c|c|c|c|c}
\hline & \multicolumn{3}{|c|}{ Brands } & \multicolumn{3}{c}{ Comparison of mean weight gain between brands } \\
\hline Caliber & Dentsply (1) & Endopoints (2) & Tanari (3) & $(1) \times(2)$ & $(1) \times(3)$ & $(2) \times(3)$ \\
\hline 15 & 2.4 & 3.4 & 3.3 & $p<0.05$ & $p<0.05$ & $p>0.05$ \\
\hline 20 & 2.8 & 3.4 & 3.7 & $p<0.05$ & $p<0.05$ & $p>0.05$ \\
\hline 25 & 3.4 & 4.0 & 5.3 & $p>0.05$ & $p<0.05$ & $p<0.05$ \\
\hline 30 & 4.4 & 4.5 & 5.4 & $p>0.05$ & $p>0.05$ & $p<0.05$ \\
\hline 35 & 4.5 & 6.8 & 7.1 & $p<0.05$ & $p<0.05$ & $p>0.05$ \\
\hline 40 & 6.4 & 7.1 & 8.1 & $p>0.05$ & $p<0.05$ & $p<0.05$ \\
\hline
\end{tabular}

* Values are in scientific notation

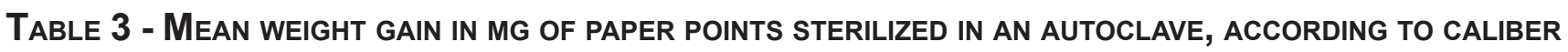
AND BRAND

\begin{tabular}{c|c|c|c|c|c|c}
\hline & \multicolumn{3}{|c|}{ Brands } & \multicolumn{3}{c}{ Comparison of mean weight gain between brands } \\
\hline Caliber & Dentsply (1) & Endopoints (2) & Tanari (3) & $(1) \times(2)$ & $(1) \times(3)$ & $(2) \times(3)$ \\
\hline 15 & 2.3 & 3.3 & 2.7 & $p<0.05$ & $p<0.05$ & $p<0.05$ \\
\hline 20 & 2.8 & 3.4 & 3.3 & $p<0.05$ & $p<0.05$ & $p>0.05$ \\
\hline 25 & 3.5 & 3.9 & 4.7 & $p>0.05$ & $p<0.05$ & $p<0.05$ \\
\hline 30 & 4.2 & 4.9 & 4.7 & $p<0.05$ & $p<0.05$ & $p>0.05$ \\
\hline 35 & 4.7 & 6.2 & 6.7 & $p<0.05$ & $p<0.05$ & $p>0.05$ \\
\hline 40 & 4.4 & 6.9 & 7.9 & $p<0.05$ & $p<0.05$ & $p<0.05$ \\
\hline
\end{tabular}

* Values are in scientific notation 
Table 4 - Comparison of mean weight gain in mg between Cell Pack paper points and Dentsply PAPER POINTS STERILIZED IN DRY HEAT OR AUTOCLAVE

\begin{tabular}{c|c|c|c|c|c|c|c}
\hline & \multicolumn{4}{|c|}{ Mean weight gain $(\mu \mathrm{g})$} & \multicolumn{2}{c}{$p$-values of Tukey's multiple comparison test } \\
\hline & Cell Pack & Dentsply: & Dentsply: & & \multicolumn{2}{c}{} \\
\hline Caliber & $(1)$ & Dry heat $(2)$ & Autoclave (3) & $p$-value & $(1) \times(2)$ & $(1) \times(3)$ & $(2) \times(3)$ \\
\hline 15 & 2.3 & 2.4 & 2.3 & 0.778 & $*$ & $*$ & $*$ \\
\hline 20 & 2.9 & 2.8 & 2.8 & 0.675 & $*$ & $*$ & $*$ \\
\hline 25 & 3.5 & 3.4 & 3.5 & 0.521 & $*$ & $p<0.05$ & $p>0.05$ \\
\hline 30 & 4.7 & 4.4 & 4.2 & 0.023 & $p>0.05$ & $*$ & $*$ \\
\hline 35 & 5.0 & 4.5 & 4.7 & 0.105 & $*$ & $*$ & $*$ \\
\hline 40 & 6.1 & 6.4 & 4.4 & $<0.001$ & $p>0.05$ & $p<0.05$ & $p<0.05$ \\
\hline
\end{tabular}

* Values are in scientific notation

\section{Discussion}

Humidity inside root canal system following biomechanical preparation and disinfection is one of the factors that influence marginal sealing of the root canal filling, with a consequent effect on the success of root canal treatment [1]. Very few studies [1,5-7, 9-14] report absorption property of absorbent paper points. There is also a lack of standardization in the study protocols, which describe methods with no specific nomenclatures, thereby hindering comparisons between studies [7]. Results of the present research are in agreement with findings described by Callahan [15], who found that the use of absorbent paper points after aspiration is the most efficient method for drying root canal prior to filling.

Results of this study are also in agreement with those reported by Edwards et al. [5], who found no correlation between point size and absorbency. The authors also report desirable properties that absorbent paper points should have: they should quickly absorb a series of medications, water, blood and fluids; they should be straight, conical, have a uniform length and a shape in compliance with International Standard Organization specifications. They should exhibit sufficient integrity (dry or wet) in order to the fibers not become detached or the tips themselves disintegrate during use; they should be clean and able to withstand sterilization by conventional methods without affecting their properties; they should also be white and odorless.

Silva et al. [9] found that paper points have an absorption capacity greater than $100 \%$ of their own weight, which was also found in the present study. In order to obtain maximal performance from the points, sufficient time should be allowed for the absorption of the irrigation solution.
Different degrees of absorption capacity were found in the three commercial brands analyzed in the present study, which is similar to the findings described by Pumarola-Suñe et al. [6]. This result may be explained by differences in fabrication processes and lots as well as the material used to make the points, paper solubility and the glue used by different manufacturers. In the present research as well as a study reported by Victorino et al. [10], Tanari paper points exhibited the best absorption capacity compared to Dentsply and Endopoints paper points. The methods employed in the present study to determine the absorption properties of the different brand of paper points were those described by Pereira et al. [7], who found that percentage of increased mass determination was the most efficient method for determining absorption properties. Similar reason was applied for the selection of $2 \%$ methylene blue as the dye solution. Tracers such as procion blue, eosin red, silver nitrate and Inda ink [16] and irrigating solutions such as saline solution [10] and sodium hypochlorite [17] have also been used. However, methylene blue, in various concentrations has been the most commonly used tracer for several decades. In addition, this coloring solution has been also used to examine the dye penetration into other materials $[7,18-20]$.

Different methods of sterilization such as dry heat, formalin tablets and electric sterilizer with marbles have been used for absorbent paper points [21]. However, the wet heat sterilization is the most used method in dentistry because it is fast and efficient [10]. Holland et al. [12], Kuga et al. [13], and Bramante et al. [14] related that when the paper points are sterilized, the absorption capacity is diminished. In this study, the sterilization (whether in an autoclave or dry heat) 
to which the paper points were submitted altered the initial integrity of the points, which lost a significant amount of their mass due to the process. Elimination of humidity occurred after both sterilization methods, included the points sterilized through wet heat (autoclave), although to a lesser degree. According to Carvalho et al. [11], dry-heat sterilization is the preferential method for sterilizing paper points, as it reduces the moisture content present in the paper point itself, thereby increasing its absorption propriety. Regarding a single sterilization cycle, the loss of humidity did not significantly alter the mean absorption capacity of the paper points. In the present study, in groups 2 and 3, the absorbent paper points were submitted to only a single sterilization cycle because according to Victorino et al. [10] and Kubo et al. [17] the absorption capacity of the paper points is influenced by the number of sterilization cycles.

Under the experimental conditions of the present study, we concluded that the Tanari paper points exhibited the best absorption capacity among the brands analyzed, but the difference was nonsignificant, and the sterilization process did not influence the absorption capacity of the absorbent paper points.

\section{Conclusions}

- $\quad$ Sterilization methods had no influence over the absorption capacity of paper points.

- Commercial brands assessed exhibited different degrees of absorption capacity in the sterilization methods employed.

- Tanari absorbent paper points achieved the best absorption capacity in comparison to Endopoints and Dentsply brand paper points.

- Dentsply Cell Pack paper points did not demonstrate a greater absorption capacity than paper points of the same brand when sterilized in either an autoclave or dry heat.

\begin{abstract}
Resumo
O objetivo do presente estudo foi analisar a influência dos métodos de esterilização sobre a capacidade de absorção de diferentes marcas de cones de papel absorvente, testando a hipótese de que existe uma correlação positiva entre o percentual de maior capacidade de absorção e o método de esterilização. Cones de papel absorvente padronizados (calibre de \# 15 a \# 40) de três marcas comerciais diferentes foram usados para este estudo (Dentsply, Endopoints, Tanari). Vinte pontas de papel absorvente de cada calibre foram utilizadas. O peso inicial de cada cone de papel absorvente foi aferido utilizando uma balança digital. Após a esterilização, o peso seco de cada cone de papel absorvente foi determinado. Em seguida, cada cone de papel foi introduzido em uma solução de azul de metileno a 2\% durante 20 segundos até a saturação completa. Os cones de papel foram removidos da solução e o peso úmido foi determinado, e a capacidade de absorção calculada a partir da diferença entre peso úmido menos o peso seco. Os dados foram analisados estatisticamente pelo teste de Tukey e o teste $\mathrm{t}$ de Student $(\mathrm{p}<0,05)$. Os cones Tanari exibiram a melhor capacidade de absorção entre as marcas analisadas, mas a diferença não foi significativa. O processo de esterilização não influenciou a capacidade de absorção dos cones de papel absorvente.
\end{abstract}

\title{
Palavras-chave
}

Cavidade pulpar; endodontia; esterilização.

\section{RefERENCES}

1. Hosoya N, Nomura M, Yoshikubo A, Arai T, Nakamura J, Cox C. Effect of canal drying methods on the apical seal. J Endod. 2000;26(5):292-4.

2. Wu MK, Van Der Sluis LWM, Ardila CN, Wesselink PR. Fluid movement along the coronal two-thirds of root fillings placed by three different gutta-percha techniques. Int Endod J. 2003;36(8):533-40.

3. Spångberg LSW, Haapasalo M. Rationale and efficacy of root canal medicaments and root filling materials with emphasis on treatment outcome. Endod Topics. 2002;2(1):35-58.

4. Aguiar CM, Coêlho MC de A, Clímaco LSS, Câmara AC. Influence of the ProTaperTM Gutta-percha master point diameter in the apical sealing. G It Endo. 2008;22(1):13-6.

5. Edwards RO, Bandypadhyay S. Physical and mechanical properties of endodontic absorvent paper points. J Endod. 1981;7(3):123-7.

6. Pumarola-Suñé J, Sold-Vicens L, Sentis-Vilalta J, CanaldaSahli C, Brau-Aguadd E. Absorbency properties of different brands of standardized endodontic paper points. J Endod. 1998;24(2):796-8.

7. Pereira CC, Gomes MS, Della Bona A, Vanni JR, Kopper PMP, Figueiredo JAP. Evaluation of two methods of measuring the absorbing capacity of paper points. Dent Mater. 2008;24(3):399-402.

8. Möller B, Hensten-Pettersen A. A biological evaluation of absorbent paper points. Int Endod J. 1985;18(3):183-6. 
9. Silva RG, Vansan LP, Pécora JD, Costa WF. Capacidade de absorção dos cones de papel absorventes de diferentes marcas. Rev Odont USP. 1989;3(2):354-6.

10. Victorino FR, Lukiantchuk M, Garcia LB, Bramante CM, Moraes IG de, Hidalgo MM. Capacidade de absorção e toxicidade de cones de papel após esterilização. RGO. 2008;56(4):411-5.

11. Carvalho MGP, Duarte GCP, Amaral MM, Milao NF. Poder de absorção das pontas de papel: influência da esterilização em estufa a seco. Avaliação in vitro. RGO. 1995;43(3):1714.

12. Holland R, Nery J, De Souza V, De Mello W, Bernabé PFE, Otoboni Filho JA. Efeito da esterilização em estufa no poder de absorção dos cones de papel. Odont Mod. 1991;18(2):6-8.

13. Kuga MC, Marcondes Neto F, Bertolini JC. Influência dos métodos de esterilização no poder de absorção dos cones de papel absorvente. Odont Mod. 1991;18(5):12-4.

14. Bramante CM, Pontes HS, Bramante AS. Efeito dos métodos de esterilização e marcas sobre o poder de absorção dos cones de papel absorvente. Rev Fac Odont Bauru. 1994;2(1):11-4.

15. Callahan JR. Sulfuric acid for opening root-canals. Dental Cosmos. 1894;36(12):957-9.

16. Öztan MD, Özgey E, Zaimoğlu, Erk N. The effect of various root canal sealers on India ink and different concentrations of methylene blue solutions. J Oral Sci. 2001;43(4):245-8.

17. Kubo CH, Gomes APM, Jorge AOC. Influência dos métodos de esterilização na capacidade e velocidade de absorção de diferentes marcas comerciais de cones de papel absorvente para endodontia. Rev Odontol UNESP. 2000;29(1/2):113-27.

18. Starkey DL, Anderson RW, Pashley DH. An evaluation of the effect of methylene blue dye $\mathrm{pH}$ on apical leakage. J Endod. 1993;19(9):435-9.

19. Xu Y, Young MJ, Battaglino RA, Morse LR, Fontana CR, Pagonis TC, et al. Endodontic antimicrobial photodynamic therapy: safety assessment in mammalian cell cultures. J Endod. 2009;35(11):1567-72.

20. Torabinejad M, Parirokh M. Mineral trioxide aggregate: a comprehensive literature review- part II: leakage and biocompatibility investigations. J Endod. 2010;36(2):190202.

21. Aguiar CM, Ximenes EC, Macedo CAB, Câmara AC. Avaliação da esterilidade dos cones de papel absorvente. Int J Dent. 2006;5(3):88-92.

Received: $24 / 10 / 2011$

Accepted: 12/01/2012

Corresponding author: Prof. Dr. Carlos Menezes Aguiar Rua Aristides Muniz, 70/501 Boa Viagem, Recife PE 51020-150 - Brazil. cmaguiar.ufpe@yahoo.com.br 